\title{
Military and Politics: Understanding the Theoretical Underpinnings of Military Incursion in Third World Politics
}

\author{
Herbert C. Edeh (Ph.D) \\ Michael I. Ugwueze (M.Sc.) \\ Department of Political Science, University of Nigeria, Nsukka, Nigeria \\ Email: ugwueze_ikechukwu@yahoo.com
}

Doi:10.5901/mjss.2014.v5n20p2047

\begin{abstract}
The study is an attempt to explain the theoretical underpinnings of military involvement in Third World politics. It raised such pertinent questions as to why military rule occurred more in Less Developed Countries than in developed ones and why is direct military involvement in politics condemned globally even when some appeared to have fared better than the prevailing corrupt civilian administrations. These questions were clarified in a study that is basically qualitative in nature using various theories of military intervention in politics to argue that so long as Third World politicians remain intransigent to their societal problems, military involvement in politics will continue to be a phenomenon to be reckoned with notwithstanding that the involvement of the Armed Forces in political life of the people has not reflected any improvement in governance. The work concludes that it would be difficult for any military rule to perform better than civilian-led administrations being a body taught to fight and kill than to govern.
\end{abstract}

Keywords: military, politics, incursion, government and rule

\section{Introduction}

Military involvement in politics either through military rule, sometimes referred to as military government or military regime, is a political phenomenon that has been characteristic of many societies especially the Third World countries. While it is regarded as a political aberration across the globe in recent times, it has continued to threaten many societies mostly in Africa even at this era of global "project democracy". For most of human history, attaching "military" to "rule" would have been redundant because almost all political regimes in large societies of the pre-modern period fused military, religious, economic and monarchical powers (Badie et al, 2011). Indeed, military rule is not a recent phenomenon because it pre-dated even the praetorianism of Roman times and was rampant during the feudal era as well as regular interregnum in the constitutional struggles of many societies, including Africa and other Third World countries especially after their political independence (Igwe, 2005). However, the separation of military and civilian powers and the development of professional and bureaucratic armed forces in European states in the $18^{\text {th }}$ and $19^{\text {th }}$ centuries gave birth to the contemporary understanding of military rule (Badie et al, 2011).

Consequently, military interventions in politics are very common both in democratic and totalitarian regimes (Onder, 2010). The "national guard" function of the military makes it very powerful and sometimes unquestionable when it begins to exert an almost unrestrained influence in government; the height of which may involve direct takeover of the institutions of governance. Even in developed countries, although the military is restricted to national defense and obedience to the civil authority, it still exerts significant influence on the government policies (Onder, 2010). Halprin (1975) argued that even in the United States, the military poses a unique set of problems for Presidents. Equally, Fourney (1977) observed that no individual can have a significant effect on military budgets, including presidents. The distinguishing factor between the military of advanced societies and those of the less developed societies is the strict adherence of the former to military professionalism imbued with national protection and the inability of the later to curtail its gluttonous political adventure and concentrate in the assigned function of national protection. The military in less developed societies have, for flimsy reasons and excuses, infiltrated the political administrative machineries of the states without correspondingly fulfilling their messianic propaganda embedded in their reasons for military takeover.

Although extant literature abounds on military rule, the involvement of the military in determining who gets what, when and how, is yet to be studied well enough. The critical questions this study sets to address are: why does military rule occur more in Less Developed Countries than in the developed ones and why is direct military involvement in politics 
condemned across the globe even when some appeared to have fared better than the prevailing corrupt civilian administrations (often mistaken to be democracy) in many Third World countries? The study also aims to clarify the ambiguities that characterize the concept of military rule and other related terms like the military government, military regime and military intervention in politics, as well as provide a better understanding of some theoretical underpinnings that underscore military interventions in politics around the world.

\section{Conceptual Clarification of Terms}

Some of the important terms that would engage our minds in this discourse include: military rule, military government, military regime and military intervention in politics. For this reason therefore, their clarifications become imperative.

\subsection{Military Rule}

The concept of military rule has often been mistaken with military government or military regime. However, there are significant differences between and among the three interrelated concepts. Igwe (2005: 268) sees military rule as:

Governance by the armed forces and the consequent reversal from civil to military superordinacy, usually through an unconstitutional takeover of power in a coup d'état that ousted the legitimate civil authority, with the pretext of either restoring law and order, re-instituting legality within the system or eradicating any other social ills affecting the state.

This definition is important for two reasons: one, it is important for its emphasis on military super-ordinacy in governance and two, the process by which military power to govern could be secured - brute force. Nevertheless, military rule can appropriately be defined as an act or process of administering a given polity by the Armed Forces which often is acquired via the seizure of state power through force. This implies that military power to govern is acquired not through the ballot papers but through the barrel of guns. So, it is a power to govern a people without their consent.

\subsection{Military Government}

A government is that agency of the ruling class that is charged with the responsibility of exercising state power on behalf of the whole classes (Nnoli, 2003). It can also be referred to as the institutionalized agency for the legitimate administration of the class society, in effect, translating into a structured organization of power for the realization of the objectives of the ruling class, and the major instrument of its practical exercise by its governing elites within the state (Igwe, 2005). However, it is important to note that not all administrations are legitimate, as this last definition would want us to believe. Military government therefore, refers to the administrative agency managed by the Armed Forces and charged with the responsibility of exercising state power on behalf of the whole social classes in a given polity. It is therefore an institution of governance that is derived unconstitutionally.

\subsection{Military Regime}

Many scholars have continued to use the term "regime" to mean a form of government or even a set of rules and basically the time or period a person rules (Wikipedia, 2013). Interestingly, a regime is synonymous with both the form of government and a set of rules. But in politics, a regime is a framework of social organization based on rules designed to regulate the operation of government and its interactions with the rest of the societies. By implication therefore, a military regime is a coercive framework of social organization that is based on regimented rules designed to compel obedience from the rest of the civil societies via the promulgation of Decrees.

\subsection{Military Intervention in Politics}

The concept of military intervention appears to be clearer when compared to military rule, military government and military regime. Unfortunately, it is the most ambiguous among the rest. For the sake of clarity, the use of military intervention in this work is strictly as it affects the seizure and use of state power by the armed forces. This is because there are many forms of military intervention. When a State of Emergency is declared and troops are deployed to maintain peace, it is a military intervention. When terrorists overrun a society and troops are sent to restore constitutional order, it is a military intervention. It is a military intervention when a country is envisaged to be building nuclear weapons and others send troops to destroy them. In fact, military intervention as a political concept can be very confusing if not properly situated. 
Military intervention in politics, in this context, can be seen as an unconstitutional takeover of political power from the civilians by the armed forces by brute force. Armed forces here include: the army, the navy, the air force, the secret police and other sabotaging law enforcement agencies (Acemoglu et al, 2010). It is unconstitutional because there are no defined rules of engagement stated anywhere as the established mechanisms on how the people can change their government. It can appropriately be called coup d'état. Coup d'état implies violent (or by whatever means) military overthrow of an elected civilian government or a constituted monarchy.

Summarily, while military rule is an act or a process of governance, military government is an institution or agency of governance and military regime is a framework of governance. It is very difficult, if at all possible, to find in a polity where there is military rule without military government and military regime; except in a diarchy where power is shared by both the military and civilian authorities. On the other hand, military intervention is also an act; though not of administering or governing, but of acquiring the political power by the armed forces. The entire process follows a concentric chain order (see the concentric diagram below).

Figure 1: concentric diagram of military relationship

Keys:

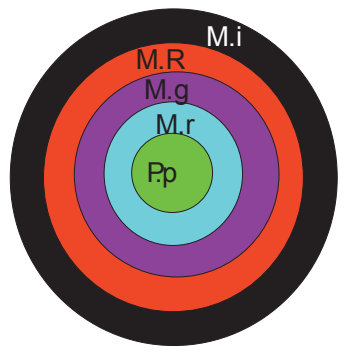

$$
\begin{aligned}
& \text { M. } \mathrm{i}=\text { military intervention } \\
& \text { M.R. = military rule } \\
& \text { M. } \mathrm{g}=\text { military government } \\
& \text { M. }=\text { military regime } \\
& \text { P. } p=\text { political power. }
\end{aligned}
$$

From the diagram, while there cannot be military rule without military intervention, there can be military intervention without military rule. The former implies that for the armed forces to control political power which constitutes the epicenter of the concentric circle, they must have to intervene first. On the other hand, the later implies that a dissatisfied military (like others in the society) might intervene to correct a societal anomie (though not often the case) and install a new government not necessarily controlled by them. The first military coup in Nigeria attests to this fact except that the civilian politicians of the time who survived the mutiny declined continuing with governance and voluntarily surrendered political power to the military who on their part exhibited high degree of insensitivity and myopism that are bereft of administrative acumen.

\section{Theories of Military Interventions in Politics}

Of all the prevailing theories of military interventions in politics, five remain outstanding. These five as articulated by Onder (2010) include:

- Socio-economic development theory

- Political development theory

- The centrality of military theory

- The conflict theory and

- Regional differences theory.

\subsection{Socio-Economic Development Theory}

The commonest of the prevailing argument of military intervention in politics and the subsequent military rule is the socioeconomic development theory. Finer (1988) cited in Onder (2010) argued that the density of military interventions in 
politics is more likely to decrease with increased socio-economic development status. Putnam (1967) further argued that, "nations with high socio-economic situations have higher urbanization, industrialization and literacy level, and so have increased mass participation into the social activities" (cited in Onder, 2010:3).

Socio-economic development creates awareness of political events and spurs political actions. In other words, it increases the number of potential political actors and diffuses increased political resources to these actors who would be willing and able to sustain civilian institutions (Onder, 2010). It is important to note that, industrialization reduces the propensity of military interventions since the increased socio-economic complexity puts public administration beyond the skills of armed forces.

The general argument here is that poverty, otherwise inadequate socio-economic development, can be a very important variable for military interventions and military rule in any society, thus, the reason why the less developed societies have witnessed more military coups than the much developed ones.

\subsection{Political Development Theory}

The political development theory is another set of variable that explains military interventions in politics around the globe as well as the attendant military rule. Although political development is closely related to the socio-economic development already discussed, it is quite distinct from it. Political development as used here is synonymous with strong civilian government, strong democratic values and strong political institutions (like the ones that exist in the United States, United Kingdom, among other advanced societies). Where these indicators of political development are found, there is high degree of fundamental human rights imbued with freedom (except for those freedoms that infringe on others' rights), rule of law, equity and justice. Where these variables are prevalent, military intervention is usually very difficult, but where they exist in a breach, the society is prone to military intervention and rule. African and other less developed countries have been advised to build strong political institutions to combat this scourge and fight underdevelopment as well (Obama, 2009).

\subsection{The Centrality of Military Theory}

In all political systems, the military possess certain advantageous characteristics which allow it to intervene in the political process (Ball and Guy-Peters, 2000). Accordingly, Jenkins and Kposowa (1992) cited in Onder (2010) argued that, the centrality of the military to the state's claim on legitimate violence makes it prone to use this to dominate politically, and especially if civilian institutions are weak. Acemoglu et al (2010) argued that the creation of a powerful military is a double-edged sword for the elite. On the one hand, a more powerful military is more effective in preventing transitions to democracy. On the other hand, it also necessitates either greater concessions to the military or raises the risk of a military takeover (Acemoglu et al, 2010). Indeed, a powerful military is not only effective in preventing a transition to democracy (in societies where they have gained control of political power) but also creates a political moral hazard problem because it can turn against the elite and take direct control of the government and consequently wield political power (in societies that are vulnerable but not yet under military rule). This argument informs why there is always greater budget allocation to defense in virtually all countries around the world, including the U.S especially America under the Republican control.

The argument of the centrality of military theory is that the stronger the military's resources, either as a percent of state resources or relative to the national economy and coupled with the "national guard" function, the weaker the institutions of civil society and thereby the greater the probability of military interventions.

\subsection{The Conflict Theory}

Conflict is part of human history and the military is also insulated in this history. Interestingly, ethnic antagonisms including cultural diversities, ethnic dominance and ethnic competitions are largely responsible for military interventions in politics especially in Africa. The second military coup in Nigeria which brought Gen. Yakubu Gowon to the corridors of power is inescapably linked to this conflict theory. It was believed by the Northerners that the coup that not only ousted Prime Minister Tafawa Balewa but also killed him along with other prominent Nigerian politicians of northern and western extractions was masterminded by the Igbos and that the subsequent ascension to power by Aguiyi Ironsi was a grand design to establish Igbo dominance in Nigeria, thus, a counter coup.

Morrison and Stevenson (1972) cited in Onder (2010) argued that the greater the number and cultural diversity of groups, the greater the elite instability and the greater the military intervention. However, this argument could be misleading because if military intervention is synonymous with societal heterogeneity, then the United States would have 
recorded the highest case of military rule in the world. Nevertheless, such is not the case. Perhaps, there is a close relationship between a society's inability to subsume its heterogeneity into a harmonious union and the military intervention in that society. Therefore, the problem is not heterogeneity per se but the inability to explore and harness the diversities into a harmonious composite union.

\subsection{Regional Differences Theory}

This theory is closely related to the conflict theory due to the fact that what often generates conflict (the type that leads to military intervention) usually issue from geographical locations and differences of the ruling class who continually explore all possible avenues to establish their dominance.

The theory of military interventions can further be explained using the following diagrams.

Figure 2: A Diagram Representing Stable Industrialized State with Little or no Threat of Military Intervention

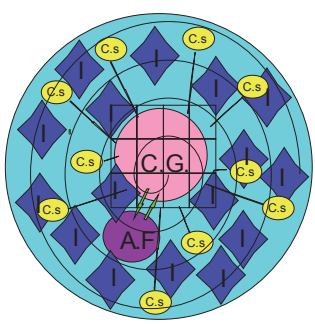

Source: developed by the authors

In the above diagram, the military does its assigned function of national protection, including shielding the Civilian Government (as represented by the square net around the pink circle labeled C.G) like the uterus does to the foetus. This is the height of military patriotism which gives the leaders (mostly found around the axis of C.G) the opportunity to provide dividends of socio-economic development (represented by the shapeless blue star labeled I) to the people including the military. The relationship between the C.G. and A.F is very cordial exemplified by the reciprocal green arrows between the C.G. and A.F as well as the close location of the 2 circles labeled C.G and A.F. The input made by the civil societies (C.S) to the government (C.G) represented by the arrows linking the C.S and the C.G has significant impact which helps in strengthening the system. The Armed Forces (A.F) in addition to shielding the C.G also provide adequate security to the rest within the state which is represented by the spiral black line around the entire society. Consequently, the high number of industries (I) creates higher urbanization and makes the administration of the society complex beyond the managerial ability of the military, hence, their disinterestedness in intervening. Advanced countries of Europe and North America fit into this.

Figure 3: A diagram representing less developed state with threat of military intervention

Source: developed by the authors

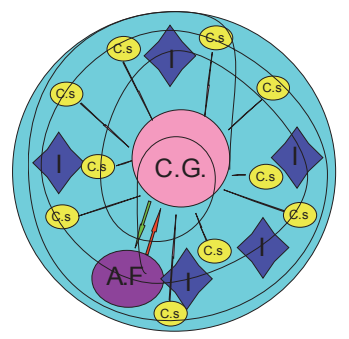

In this figure 3, the professional military institution represented by the circle labeled A.F in the diagram looms larger than what exists in the figure 2. In this state, the military still retains its security function but with an eagle eye to what the politicians do within the C.G (represented by the red arrow linking the A.F with C.G) and the politicians are also skeptical of what the military would do, hence, the little bit distant location of the 2 circles labeled A.F and C.G. The green and red 
arrows linking both the C.G. and A.F suggest that the two institutions are suspicious of each other. The military does not shield the C.G like it does in the figure 2. This shows gradual erosion of military patriotism. Because this society is less developed, with little industries, it is not so complex to administer like the one in diagram A. Thus, the military can intervene and rule as well. This state is vulnerable to military intervention and rule. Democratic societies in the Third World countries, including Nigeria fit into this.

Figure 4: A diagram representing a state under military rule

Source: developed by the authors

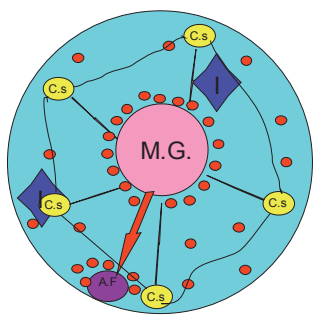

In this state, the utmost concern of the military government (M.G.) is how to retain and maintain political power and not how to provide social services. There are little or no industries (because the hitherto existing ones have been rendered redundant), less civil societies (because their leaders have been incarcerated and there is no freedom of expression) and even the military institution (A.F) has been shrunk with red eagle eye (represented by the red arrow from M.G. to A.F) to ensure no counter coup from the military quarters. The military government (M.G.) encircles itself with informants (represented by the small red circles) with others extending to the armed forces and little scattered to the society to ensure compliance. This state has no security; there is no reciprocal relationship between the M.G. and the A.F but there is greater co-operation among the surviving civil societies (C.S) represented by the linking black lines.

Summarily, it is difficult, if not impossible, for the states that fit into diagram A to experience military intervention without first degenerating into the condition of the states in diagram B. It also follows that countries that fit into category $\mathrm{B}$ diagram, however they sing democracy like song, without making meaningful efforts to industrialize thereby making the administration of the state complicated for the armed forces, they should expect military rule and that includes Nigeria.

Against this backdrop, we can make the following deductions about military interventions in politics:

- Military intervention in politics is less likely to take place in countries with high rate of socio-economic development.

- Military intervention in politics is less likely to happen in countries with well-developed political institutions.

- Military intervention is more likely to take place in countries where military institutions are in a central role.

- Military intervention in politics is more likely to take place in countries with disarticulated heterogeneous structure imbued with ethnic antagonisms and ethnic dominance.

- Military intervention is more likely to be rampant in Africa, Latin America and Asia. This is because they possess the qualities that make a society vulnerable to military intervention as outlined above.

\section{Understanding the Dynamic Consequences of Military Rule in Global Arena}

The New World Order views military rule as a manifestation of repugnant society that is characteristic of political instability. Like it was earlier stated, military intervention in politics pre-dates the modern state system and it was one of the greatest means of exercising dominance and wielding power especially at the time of warlordism (Igwe, 2005). In fact, it was an act of military intervention that a man or group of men could catch their fellow men and subject them to life of slavery which characterized the life of man at the historical epoch called the slave-holding era. The first military coup, strictly so called, took place in 632BC in Athens involving Cylon who attempted to establish himself as a tyrant but failed. The next was in 509BC involving the members of the Tarquin Dynasty led by Lucius Junius Brutus which overthrew King of Rome, Lucius Tarquinius Superbus and the result was the establishment of the Roman Republic (Bingham, 1950). The last of military coup recorded before Christ was that involving Julius Ceasar on the Ides of March, 44BC which was led by members of the Roman Senate.

Similarly, understanding the dynamic consequences of military rule in the global arena elicits a corresponding 
understanding of the history of military interventions in politics around the world; especially after the Second World War when more states emerged in the international system.

Table 1: Instances of military interventions and attempted coups around the world between 1945 and 2013

\begin{tabular}{|c|c|c|c|}
\hline Year & Country & Region/Continent & Coup attempted and leadership result \\
\hline 1945 & Brazil & S/America & Getulio Vargas government ended in a coup led by General Mourao, one his former supporters \\
\hline - & Venezuela & S/America & $\begin{array}{l}\text { Isaias Medina Angerita was overthrown in a coup and Romulo Betancourt was appointed to lead a } \\
\text { civilian-military junta }\end{array}$ \\
\hline 1947 & Thailand & Asia & Thawal Thamrong Navaswadhi was ousted and Plack Pibulsonggram returned \\
\hline- & Romania & Europe & Communist coup which force king Michael to abdicate \\
\hline- & Czechoslovakia & Europe & Communist coup \\
\hline - & Venezuela & S/America & $\begin{array}{l}\text { Democratic government of Romulo Gallegos was overthrown and a military junta Carlos Delgado } \\
\text { Chalband installed as leader }\end{array}$ \\
\hline - & Yemen & Asia & Failed coup attempt in Mutawakkilite \\
\hline 1949 & Syria & Asia & Military coup by General Husni al-Za'im against president Shukri al-Quwatli \\
\hline 1951 & Thailand & Asia & Unsuccessful coup led by the Navy \\
\hline- & Thailand & Asia & Successful coup led by the Army \\
\hline- & Pakistan & Asia & Unsuccessful military coup attempt led by Ayub Khan \\
\hline- & Argentina & S/America & Unsuccessful military coup against Juan Domingo Peron \\
\hline 1952 & Egypt & Africa & Military coup which overthrew the monarchy \\
\hline-1 & Cuba & ClAmerica & Successful bloodless coup led by Fulgenco Batista against democratically elected Cuban government \\
\hline 1953 & Iran & Asia & Joint US/UK coup codenamed Operation Ajax which overthrew Prime Minister Mohammed Mosaddeq \\
\hline - & Pakistan & Asia & $\begin{array}{l}\text { Constitutional coup by Governor-General, Ghulam Mohammed and supported by field marshal Ayub } \\
\text { Khan. Mohammed dismissed the Prime Minister and dissolved the Constituent Assembly }\end{array}$ \\
\hline 1954 & Guatemala & C/America & $\begin{array}{l}\text { Democratically elected government of col. Jacobo Arbez Guzman was ousted by col. Carlos Castillo } \\
\text { Armas in an operation organized by CIA codenamed PBSUCCESS }\end{array}$ \\
\hline- & Paraguay & S/America & Military coup \\
\hline - & $\begin{array}{l}\text { Yanaon (French } \\
\text { Colony in India) }\end{array}$ & Asia & Military coup led by Dadala Raphael Ramanayya which overthrew French rule in Yanaon \\
\hline 1955 & Brazil & S/America & A counter coup led by Marshal Lott overthrew the government of Carlos Luz \\
\hline$-e^{\prime}$ & Argentina & S/America & Military coup overthrew president Juan Domingo Peron \\
\hline 1956 & Cuba & C/America & Unsuccessful military coup attempt by Ramon Barquim against president Fulgenco Batista \\
\hline - & Colombia & S/America & $\begin{array}{l}\text { The Colombian military supported strikes and student riots and deposed Gustavo Rojas Pinilla, giving } \\
\text { power to the military junta and chairman Gabriel Paris Gordillo }\end{array}$ \\
\hline- & Thailand & Asia & Ouster of Plack Pibulsonggram \\
\hline 1958 & Venezuela & S/America & $\begin{array}{l}\text { After } 3 \text { weeks of protest, the Venezuelan military removed Marcos Perez Jimenez and installed } \\
\text { Wolfgang Larrazabal, a commander of Venezuelan Navy }\end{array}$ \\
\hline - & Pakistan & Asia & $\begin{array}{l}\text { Army chief and defense minister, Ayub Khan, overthrew the government of Iskander Mirza to become } \\
\text { president }\end{array}$ \\
\hline - & France & Europe & $\begin{array}{l}\text { General Jacques Massu took over Algiers and threatened to invade Paris unless Charles de Gaulle } \\
\text { became head of state }\end{array}$ \\
\hline 1959 & Brazil & S/America & Air force military hijacked a civil airplane and attempted a coup against Juscelino Kubitschek \\
\hline 1960 & Turkey & Asia & Military coup \\
\hline - & DRC & Africa & Military coup \\
\hline- & Ethiopia & Africa & Failed military coup against Haile Selassie I \\
\hline 1961 & South Korea & Asia & $\begin{array}{l}\text { Coup d'état led by Park Chung Hee which overthrew Second Korea and established the supreme } \\
\text { council for National Reconstruction. }\end{array}$ \\
\hline - & France & Europe & $\begin{array}{l}\text { Failed military coup in the midst of the Algerian War by } 4 \text { retired army generals seeking to overthrow } \\
\text { president Charles de Gaulle who himself became president through } 1958 \text { coup }\end{array}$ \\
\hline 1962 & Argentina & S/America & President Arturo Frondizi was overthrown while he was abroad \\
\hline- & Dominican Republic & America & President Juan Bosch was overthrown by the military \\
\hline- & Yemen & Asia & Coup in Mutawakkilite kingdom \\
\hline- & Sri Lanka & Asia & Attempted military coup led by Christian officers in Ceylon \\
\hline- & Burma & Asia & $\begin{array}{l}\text { Military coup led by Ne Win which overthrew constitutionally elected government of Prime Minister U } \\
\mathrm{Nu}\end{array}$ \\
\hline 1963 & Guatemala & C/America & Miguel Ydigoras Fuentes overthrown by the military and Peralta Azurdia took over \\
\hline-1 & Turkey & Asia & Failed military coup \\
\hline- & South Vietnam & Asia & Military coup which overthrew Ngo Dinh Diem with US support \\
\hline- & Ecuador & S/America & Military coup \\
\hline - & Togo & Africa & Military coup \\
\hline- & Syria & Asia & Military coup \\
\hline - & Iraq & Asia & Military coup led by Baathist leader in Baghdad which overthrew Gen. Abd al-Karim Qasim \\
\hline- & Dominican Republic & America & President Juan Bosch was overthrown \\
\hline- & Honduras & C/America & Military coup against a democratic government \\
\hline 1964 & Zanzibar & & Local revolutionaries overthrew Sultan Jamshid bin Abdullah \\
\hline
\end{tabular}




\begin{tabular}{|c|c|c|c|}
\hline- & Brazil & S/America & $\begin{array}{l}\text { Humberto Castelo Branco was installed as president after a military coup which overthrew Joao } \\
\text { Goulart }\end{array}$ \\
\hline- & Bolivia & S/America & $\begin{array}{l}\text { Vice President Reni Barrientos and Gen. Alfredo Ovando Candia overthrew President Victor Paz } \\
\text { Estenssoro }\end{array}$ \\
\hline- & South Vietnam & Asia & The government of Duong Van Minh was overthrown \\
\hline- & Bolivia & S/America & Victor Paz was replaced with Rene Barriento Ortuno \\
\hline- & Gabon & Africa & Brief military coup was suppressed with the aid of France \\
\hline 1965 & Algeria & Africa & Defense Minister, col. Honari Boumedienne took over after military coup \\
\hline- & Indonesia & Asia & Military coup \\
\hline- & DRC & Africa & Military coup \\
\hline & $\begin{array}{l}\text { Central African } \\
\text { Republic }\end{array}$ & Africa & Military coup \\
\hline 1966 & Ghana & Africa & Military coup \\
\hline \begin{tabular}{|c|c|}
- \\
\end{tabular} & Burkina Faso & Africa & Military coup led by Sangoule Lamizana overthrew Maurice Yameogo \\
\hline- & Syria & Asia & Military coup \\
\hline- & Nigeria & Africa & First military coup tha brought Aguiyi Ironsi to power \\
\hline- & Abu Dhabi & Asia & $\begin{array}{l}\text { Bloodless coup that deposed Shakhbut Bin-Sultan al Nahyan and installed his brother Sheikh Zayed } \\
\text { bin Sultan Al Nahyan }\end{array}$ \\
\hline- & Nigeria & Africa & Military coup that brought Yakubu Gowon to power \\
\hline- & Argentina & S/America & Civilian President Arturo Illia was overthrown by military forces \\
\hline 1967 & Greece & Europe & Military coup \\
\hline- & Ghana & Africa & Attempted military coup (Operation Guitar Boy) \\
\hline- & Togo & Africa & Military coup which led to thirty-eight year rule of Gnassingbe Eyadema \\
\hline- & Sierra Leone & Africa & $\begin{array}{l}\text { Military coup against Prime Minister Siaka Stevens led by Brigadier David Lansana who declared } \\
\text { himself interim leader }\end{array}$ \\
\hline 1968 & Panama & C/America & Coup against president Arnulfo Arias Madrid led by Omar Torrijos \\
\hline- & Iraq & Asia & Military coup that brought Ba'ath party to power \\
\hline- & Peru & S/America & Military coup led by General Juan Velasco Alvarado \\
\hline- & Sierra Leone & Africa & Military coup led by Brigadier Andrew Juxon-Smith that restored Siaka Stevens as Prime Minister \\
\hline 1969 & Libya & Africa & Muammar al-Gaddafi overthrew the monarchy \\
\hline- & Somalia & Africa & Military coup \\
\hline- & Sudan & Africa & Military coup \\
\hline- & Brazil & S/America & Brazil replaced by military junta after Artur da Costa e Silva left office due to stroke \\
\hline - & Pakistan & Asia & $\begin{array}{l}\text { Military coup led by Army Chief gen. Yahya Khan which forced President, Field Marshal Ayub Khan to } \\
\text { hand power to him }\end{array}$ \\
\hline 1970 & Syria & Asia & Coup led by Hafez al-Assad \\
\hline \begin{tabular}{|l|l|}
- \\
\end{tabular} & Bolivia & S/America & Coup which was soon followed by leftist counter coup \\
\hline- & Oman & Asia & Qaboos bin Said ousted his father Said bin Taimur to become Sultan \\
\hline- & Italy & Europe & Coup attempt by fascist group \\
\hline- & Japan & Asia & Coup attempt by Tatenokai \\
\hline- & Cambodia & Asia & Military ousted Norodom Sibanouk and installed Lon Nol \\
\hline \begin{tabular}{|l|l|}
- \\
\end{tabular} & Chile & S/America & US planned constitutional coup to prevent Salvador Allende from assuming power after being elected \\
\hline 1971 & Turkey & Asia & Military coup against government of Gaafar Nimeiry \\
\hline 1972 & Ghana & Africa & $\begin{array}{l}\text { Col. Ignatius Kutu Acheampong overthrew democratically elected government of Dr Kofi Busia on } 13^{\text {th }} \\
\text { January }\end{array}$ \\
\hline 1973 & Chile & S/America & Roberto Souper launched a failed coup against Salvador Allende \\
\hline - & Pakistan & Asia & Unsuccessful coup to oust the government of Zulfigar Ali Bhutto \\
\hline- & Chile & S/America & September 11 military coup ousted Allende and installed Augusto Pinochet \\
\hline- & Uruguay & S/America & President Juan Maria Bordaberry dissolved Parliament and staged a self-coup \\
\hline- & Greece & Europe & $\begin{array}{l}\text { On } 25^{\text {th }} \text { November, army hardliners led by Brig. Dimitrios Ioannidis overthrew the leader of Greek } \\
\text { junta, President Georgios Papadopoulos }\end{array}$ \\
\hline 1974 & Portugal & Europe & A leftist military coup ended the dictatorship of Marcello Caetano \\
\hline- & Cyprus & Asia & $\begin{array}{l}\text { Military coup sponsored by Greek colonels which overthrew Makarios and triggered invasion by } \\
\text { Turkey }\end{array}$ \\
\hline- & Ethiopia & Africa & Military coup by communist junta led by Gen. Aman Andos and Mengistu Haile Mariam \\
\hline 1975 & Bangladesh & Asia & $\begin{array}{l}\text { Young military majors overthrew the government of Sheikh Mujibur Rahman and installed Khondakar } \\
\text { Mustaq Ahmed as head of state }\end{array}$ \\
\hline- & Comoros & Africa & Mercenary Bob Denard removed President Ahmed Abdallah through an armed coup \\
\hline- & Nigeria & Africa & Military coup overthrew Yakubu Gowon and brought Murtala Ramat Mohammed to power \\
\hline- & Bangladesh & Asia & $\begin{array}{l}\text { Military coup led by Brig. Khaled Mosharraf arrested army chief of staff, Ziaur Rahman. } 4 \text { days later, } \\
\text { Khaled was killed in a counter coup led by Abu Taher which freed Rahman and restored him army } \\
\text { chief. A month later, Rahman betrayed Taher, killed him and became president }\end{array}$ \\
\hline- & Chad & Africa & Military coup overthrew and killed president Francois Tombalbaye \\
\hline & Greece & Europe & Failed military coup \\
\hline 1976 & Ecuador & S/America & Military coup \\
\hline- & China & Asia & Marshall Ye Jianying and political leader Hua Guofeng staged a coup against the Gang of Four led by \\
\hline
\end{tabular}




\begin{tabular}{|c|c|c|c|}
\hline & & & $\begin{array}{l}\text { Chairman Mao Zedong's widow, Jiang Qing and leading to return of Deng Xiaoping and the launch of } \\
\text { China's reform era }\end{array}$ \\
\hline- & Thailand & Asia & Military coup \\
\hline- & Nigeria & Africa & Failed military coup which killed Murtala and brought his Deputy Olusegun Obasanjo to power \\
\hline- & Argentina & S/America & Military coup overthrew Isabel Martinez de Peron \\
\hline 1977 & Pakistan & Asia & $\begin{array}{l}\text { Army chief Gen. Muhammad Zia-ul-Haq overthrew civilian government of Prime Minister Zulfiqar Ali } \\
\text { Bhutto and hanged him after a sham trial }\end{array}$ \\
\hline - & Bangladesh & Asia & Failed coup \\
\hline 1978 & Afghanistan & Asia & Communist coup \\
\hline- & Somalia & Africa & Failed coup against Said Barre \\
\hline 1979 & Iran & Asia & Attempted coup backed by the US \\
\hline- & South Korea & Asia & Coup d'état on $12^{\text {th }}$ December \\
\hline 1980 & Bolivia & S/America & Cocaine coup led by Lius Garcia Mezatejada \\
\hline- & Turkey & Asia & Military coup \\
\hline - & Liberia & Africa & $\begin{array}{l}\text { Military coup led by Sergeant Samuel K. Doe overthrew President William R. Tolbert ending } 102 \text { years } \\
\text { of continuous rule by the True Whig party }\end{array}$ \\
\hline - & Guinea Bissau & Africa & Military coup \\
\hline- & Suriname & S/America & Successful coup led by Desi Bouferse that resulted in military rule until 1988 \\
\hline 1981 & Spain & Europe & Failed coup led by Antonio Tejero \\
\hline- & Gambia & Africa & Failed coup led by Kukoi Sanyang \\
\hline- & Bangladesh & Asia & Failed military coup which killed Ziaur Rahman \\
\hline- & Suriname & S/America & Failed coup led by Wilfred Hawker \\
\hline- & $\begin{array}{l}\text { Central African } \\
\text { Republic }\end{array}$ & Africa & Bloodless coup which overthrew president David Dacko and brought Gen. Andre Kolingba to power \\
\hline - & Ghana & Africa & $\begin{array}{l}\text { Successful military coup led by Flt. Lt. Jerry Rawlings overthrew Dr Hilla Limann's constitutional } \\
\text { government }\end{array}$ \\
\hline- & Seychelles & Africa & Failed coup by Mike Hoare \\
\hline- & Poland & Europe & Successful military coup led by Wolciech Jaruzelski \\
\hline 1982 & Bangladesh & Asia & $\begin{array}{l}\text { Military coup led by Gen. Hossain Mohammed Ershad overthrew constitutional government of Adbus } \\
\text { Sattar }\end{array}$ \\
\hline- & Kenya & Africa & Failed coup led by some members of Kenyan air force \\
\hline- & Suriname & S/America & Failed coup led by Surendre Rambocus \\
\hline 1983 & Nigeria & Africa & Military palace coup led by Mohammadu Buhari \\
\hline- & Grenada & C/America & Military coup led by Hudson Austin and counter coup and invasion with the US support \\
\hline 1984 & Cameroun & Africa & Failed coup led by some members of the presidential guard \\
\hline - & Mauritania & Africa & $\begin{array}{l}\text { Maaouya Ould Sid'Ahmed Taya rose to power after president Mohammed Khouna Ould Haidalla was } \\
\text { overthrown }\end{array}$ \\
\hline - & Guinea & Africa & Coup which brought Lansana Conte to power \\
\hline 1985 & Uganda & Africa & Military coup led by Bazillo Olara-Okello and Tito Okello \\
\hline- & Nigeria & Africa & Military coup led by Ibrahim Babangida \\
\hline- & Sudan & Africa & Military coup led by Adbel Rahman Swar al-Dahab \\
\hline 1986 & Philippines & Asia & $\begin{array}{l}\text { failed coup led by Juan Ponce Enrile and Gregorio Honasan which led to the People's Revolution of } \\
\text { February 22-25, } 1986\end{array}$ \\
\hline 1987 & Argentina & S/America & Failed coup led by the Carapintada Movement of Aldo Rico \\
\hline- & Philippines & Asia & Failed coup led by col. Gregorio Honasan \\
\hline- & Fiji & Oceania & $\begin{array}{l}\text { Bloodless coup led by Lt. Col. Sitiveni Rabuka which overthrew the government of Timoci Bavadra. } \\
\text { After temporarily handing power to the Council of Ministers, he deposed Queen Elizabeth II and } \\
\text { declared Fiji a republic }\end{array}$ \\
\hline- & Burkina Faso & Africa & President Thomas Sankara was assassinated in a coup \\
\hline - & Tunisia & Africa & $\begin{array}{l}\text { Bloodless palace coup led by Prime Minister Gen. Zine El Abidine Ben Ali which overthrew Habib } \\
\text { Bourguiba }\end{array}$ \\
\hline 1988 & Burma & Asia & Military coup that crushed the Four Eight's uprising \\
\hline- & Argentina & S/America & Failed military coup in January \\
\hline - & Argentina & S/America & Failed military coup in December \\
\hline- & Haiti & C/America & Coup d'etat that overthrew Henri Namphy \\
\hline 1989 & Philippines & Asia & Failed coup attempt by col. Gregorio Honasan \\
\hline- & Ethiopia & Africa & Failed coup attempt by senior army officers against Col. Mengistu Haile Mariam \\
\hline- & Paraguay & S/America & Successful military coup led by Andres Rodriguez against Alfredo Stroessner \\
\hline- & Panama & C/America & Failed coup attempt by Moises Girddi against Manuel Noriega \\
\hline 1990 & Nigeria & Africa & Failed military coup led by Gideon Orkar \\
\hline- & Trinidad \& Tobago & Caribbean America & Failed coup led by Jamaat al-Muslimeen leader Yasin Abu Bakr \\
\hline - & Argentina & S/America & $\begin{array}{l}\text { Failed military against president Carlos Saul Menem led by the Carapintada movement of Mohammed } \\
\text { Ali Seineldin }\end{array}$ \\
\hline - & Panama & C/America & Failed coup against president Guillermo Endara \\
\hline- & Chad & Africa & Military coup led by Idriss Deby which deposed Hissene Habre \\
\hline 1991 & Suriname & S/America & President Ramsewak Shankar dismissed by telephone by the military on December 24 \\
\hline
\end{tabular}




\begin{tabular}{|c|c|c|c|}
\hline- & Soviet Union & Russia & Failed coup attempt in August \\
\hline - & Haiti & C/America & $\begin{array}{l}\text { Military coup that ousted Bertrand Aristide and installed military junta Raoul Cedras until US President } \\
\text { ordered Aristide to return and resume his mandate }\end{array}$ \\
\hline - & Thailand & Asia & Military coup \\
\hline - & Georgia & Europe & Military coup removed president Zviad Gamsakhurdia from office \\
\hline- & Mali & Africa & Military deposed Moussa Traore \\
\hline 1992 & Algeria & Africa & Military cancelled elections and forced president Chadli Bendjedid to resign \\
\hline \begin{tabular}{|c|c|}
- & 0 \\
\end{tabular} & Peru & S/America & Unsuccessful coup led by Jaime Salinas Sedo against Alberto Fujimori \\
\hline- & Venezuela & C/America & $\begin{array}{l}\text { Two unsuccessful coups against Carlos Andres Perez in February and November; the first led by } \\
\text { Hugo Chavez }\end{array}$ \\
\hline- & Sierra Leone & Africa & Valentine Strasser took over power \\
\hline 1993 & Russia & $\begin{array}{l}\text { Europe/Asia now } \\
\text { Russia }\end{array}$ & President Boris Yeltsin launched a self-coup, illegally dissolving the Russian Parliament \\
\hline - & Guatemala & C/America & $\begin{array}{l}\text { President Jorge Serrano Elias launched an unsuccessful self-coup, dissolving the Parliament but was } \\
\text { later removed by the court }\end{array}$ \\
\hline- & Azerbaijan & Europe & President Abulfaz Elchibey was overthrown \\
\hline- & Nigeria & Africa & Palace coup that removed Ernest Shonekan and bought in Gen. Sani Abacha \\
\hline 1994 & Gambia & Africa & Military coup \\
\hline 1995 & Azerbaijan & Europe & Failed coup attempt \\
\hline 1996 & Burundi & Africa & Sylvester Ntibantunganya deposed by Pierre Buyoya in a military coup \\
\hline \begin{tabular}{|c|c|}
- \\
\end{tabular} & Iraq & Asia & Failed military coup against Saddam Hussein \\
\hline 1997 & Turkey & Asia/Europe & $\begin{array}{l}\text { Military-backed indirect coup named postmodern coup. Although the Parliament was not dissolved, } \\
\text { the Prime Minister was forced to resign }\end{array}$ \\
\hline 1998 & Albania & Europe & Fatos Nano hastily stepped down and fled after he was attacked \\
\hline 1999 & Pakistan & Asia & Military coup \\
\hline- & Ivory Coast & Africa & First coup since its independence in 1960 \\
\hline 2000 & Ecuador & S/America & $\begin{array}{l}\text { Protest against economic policies of president Jamil Mahuad led to the takeover by col. Lucio } \\
\text { Gutierrez but within hours Vice President Gustavo Noboa regained control. Gutierrez was later elected } \\
\text { president due largely to his support for the protest }\end{array}$ \\
\hline- & Fiji & Oceania/Australia & Coup attempt by George Speight against Prime Minister Mahendra Chaudhry \\
\hline - & Solomon Islands & Oceania/Australia & $\begin{array}{l}\text { Coup against Prime Minister Bartholomew Ulufa'alu was forced to resign and was replaced by } \\
\text { Manasseh Sogavare }\end{array}$ \\
\hline 2002 & Ivory Coast & Africa & Coup attempt on September 19 \\
\hline 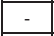 & Venezuela & S/America & Failed coup attempt which lasted about 47 hours \\
\hline 2003 & $\begin{array}{l}\text { Central African } \\
\text { Republic }\end{array}$ & Africa & Military coup against Ange-Felix Patasse \\
\hline- & Mauritania & Africa & Attempted coup \\
\hline & $\begin{array}{l}\text { Sao Tome \& } \\
\text { Principe }\end{array}$ & Africa & Military coup against Fradique de Menezes \\
\hline- & Guinea Bissau & Africa & Military coup against Kumba Lala \\
\hline- & Philippines & Asia & Failed mutiny led by the right-wing junior officers known as the Magdalo \\
\hline 2004 & Haiti & C/America & President Jean-Bertrand Aristide was ousted in his second term \\
\hline$-\left.\right|^{-}$ & Chad & Africa & Failed coup d'état against president Idriss Deby \\
\hline- & DRC & Africa & Second attempted coup in June \\
\hline- & Equatorial Guinea & Africa & Attempted coup \\
\hline 2005 & Ecuador & S/America & Coup resulted in pre-mature end of president Lucio Edwin Gutierrez Borbua \\
\hline \begin{tabular}{|l|}
- \\
\end{tabular} & Togo & Africa & Coup that was legalized by the Parliament but rejected by the international community \\
\hline- & Nepal & Asia & King Gyanendra overthrew government in a self-coup \\
\hline- & Mauritania & Africa & Military coup overthrew Maaouya Ould Sid' Ahmed Taya \\
\hline 2006 & Philippines & Asia & Attempted coup by the armed forces which led to the declaration of State of Emergency \\
\hline- & Thailand & Asia & $\begin{array}{l}\text { Prime Minister Thaksin Shinawatra was overthrown while he was outside the country by the Royal } \\
\text { Thai Army }\end{array}$ \\
\hline- & Madagascar & Africa & Alleged military coup against president Marc Ravalomanana \\
\hline- & Fiji & Oceania/Australia & Bloodless military coup overthrew president Josef Iloilo and Prime Minister Laisenia Qarase \\
\hline- & Ivory Coast & Africa & Military coup targeting president Laurent Gbagbo foiled \\
\hline 2007 & Turkey & Asia/Europe & Attempted military coup called "e-coup" \\
\hline 2008 & East Timor & Asia & President Jose Ramos-Horta was shot but the coup was foiled \\
\hline$-{ }^{-}$ & Mauritania & Africa & President Sidi Ould Cheikh Abdallahi and Prime Minister were seized \\
\hline 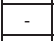 & Guinea & Africa & Military coup after the death of Lansana Conte \\
\hline 2009 & Madagascar & Africa & Attempted coup seized one of the presidential palaces. Marc was later forced to resign by the military \\
\hline- & Honduras & C/America & The army seized one of the presidential palaces and kidnapped the president Manuel Zelaya Rosales \\
\hline 2012 & Maldives & Asia & Coup of $7^{\text {th }}$ February and military dictator Dr Mohammad Waheed Hassan is currently ruling \\
\hline 2013 & Egypt & Africa & Full scale coup on $30^{\text {th }}$ June by the military dictator Abdel Fattah el-Sisi \\
\hline 2014 & Thailand & Asia & $\begin{array}{l}\text { Thai military led by the Army Chief, General Prayuth Chan-ocha, seized power on } 22^{\text {nd }} \text { May following } \\
\text { a protracted crisis in Thailand }\end{array}$ \\
\hline
\end{tabular}

Sources: http://en.wikipedia.org/wiki/list_of_coup_d'etat_and_coup_attempts and The New York Times, 22 May 2014 
From the above table, military interventions in politics occurred more after the World War II following a sporadic emergence of states in the international system; especially in Africa, Latin America, Asia and Eastern Europe that are collectively dubbed "Third World Countries". Besides the table, the figures suggest that more military interventions in politics will likely continue to occur in the Third World Countries so long as their politicians remain intransigent to solving myriads of societal problems especially those bordering on security, poverty and disease. Accordingly, Ball and GuyPeters rightly observed that:

Readers fortunate enough to live in stable democratic countries will probably not think much about the role of the military in political life. In the (larger) remainder of the world in which democracy is far from assured, however, the military is often an active component of political life. The lengthy list of successful and unsuccessful direct interventions by the military in Central and South America, the Middle-East, the new African states, Asia and several European countries since 1945 (and beyond) creates the Impression that seizure of political control by the armed forces, or the military ensuring the replacement of one civilian government by another, has been the norm rather than the exception in modern political systems (Pinkey, 1990 cited in Ball and Guy-Peters, 2000: 264).

The contemporary understanding of military rule equates it with political instability, and the more there are such rules, the more unstable the region becomes and the more security threats the world faces at large. Deriving from the table, more military interventions and rules have taken place in Asia, especially the Middle-East, Africa and Latin America; thereby supporting the argument that military rules create political instability (as the crises in the Middle-East and Africa have shown). This is why the United Nations, the African Union and other world governing bodies have abhorred military rule of whatever form and are not hesitant in imposing sanctions to any country where such mutiny takes place. To maintain international peace and security (the cardinal objectives of the United Nations under which other regional and sub-regional organizations derive their strengths), the people must be allowed to decide how they wish to be governed which military dictatorships and other forms of totalitarian rules do not encourage; hence, posing security threats to the international system.

At this juncture and coming from a Nigerian background, one can state that if the problem of Boko Haram insurgence is not properly handled and on time too by both the Nigerian politicians and the world governing bodies, then Nigeria may face another military intervention in politics. Once that happens, the entire African continent and the black race are not free and by extension, the United Nations may have more problems to contend with which will not be healthy for the peace of the international system.

\section{Conclusion}

Military rule has become infamous in recent time sequel to its restriction of the fundamental human rights, abrogation of the people's constitution and in its place, the promulgation and use of decrees, as well as the denial of the people their inalienable rights to participate in governance and the subsequent security threats such rule poses to the concerned society and the world at large. In order to curb military interventions in politics while retaining their provision of security duty, reformation of the military to enhance its professionalism has been suggested. In fact, the study has shown that the armed forces fair better under civil authority than under the military rule.

The dictum that the worst civil rule is better than the best military dictatorship is not a mere declaration of intent but a verifiable statement of fact. It is so because only civil authority can guarantee majority participation in governance and if not for anything, for the ability of the people to discharge their voting rights which is always denied under military rule. The work substantially dealt with the clarification of such concepts like military rule, military government, military regime and military intervention. From the theories of military rule and interventions among which are: the socio-economic development theory, the political development theory, the centrality of military theory, the conflict theory and the regional differences theory, we concluded that:

- Military intervention in politics is less likely to take place in countries with high rate of socio-economic development.

- Military intervention in politics is less likely to happen in countries with well-developed political institutions.

- Military intervention is more likely to take place in countries where military institutions are in a central role.

- Military intervention in politics is more likely to take place in countries with disarticulated heterogeneous structure imbued with ethnic antagonisms and ethnic dominance.

- Military intervention is more likely to be rampant in Africa, Latin America and Asia. This is because they possess the qualities that make a society vulnerable to military intervention as outlined above.

However, the type of intervention, whether merely seeking influence or that of establishing a military dictatorship, will vary according to several criteria: the nature of the political system (that is, whether the society is heterogeneously 
disarticulated), the stability of the political institutions and the level of socio-economic development (Ball and Guy-Peters, 2000).

In a nutshell, the work revealed why military rule has been largely condemned in the recent time. This condemnation is not unconnected to the security threats such rule poses to the international community; thereby threatening the world peace and security. Hence, the abhorrence from the United Nations, the African Union and other world governing bodies.

\section{References}

Acemoglu, D., Ticchi, D. and Vindigni, A. 2010. A Theory of Military Dictatorships. American Economic Journal: Macroeconomics, 2(1): $1-42$

Badie, B., Berg-Schlosser, D. and Morlino, L. 2011. Military Rule. International Encyclopedia of Political Science, 8.

Ball, A.R. and Guy-Peters, B. 2000. Modern Politics and Government. London: Macmillan Press Ltd

Bingham, W. 1950. Li Shih-Min's Coup in A.D. 626.1: The Climax of Princely Rivalry. Journal of the American Oriental Society, 70(2)

Egbo, S. 2001. Political Soldiering: Africa's Men on Horse Back. Enugu: John Jacobs Classic Publishers Ltd.

Finer, S.E. 1988. The Man on Horseback. Bourdr. Co: Westview Press

Fourney, D. 1977. Congress and the Budgetary Process: The Politics of Military

Appropriations. In J. Brigham, ed. Making Public Policy (65-137). Massachusetts: D.C. Health and Company

Halprin, M.H. 1975. The President and Military. In N.C. Thomas, ed. The Presidency in Contemporary Context (277-289). New York: Dodd, Mead and Company

Igwe, O. 2005. Politics and Globe Dictionary. Aba: Eagle Publishers

Jenkins, T.C. and Kposowa, A.S. 1992. The Political Origins of African Military Coups. International Studies Quarterly, 36: 271-292

Nnoli, O. 2003. Introduction to Politics. Enugu: Snaap Press Ltd

Obama, B. 2009. Obama in Ghana. <http://www.usaraf.army.mil>. Consulted 15 October 2013

Onder, M. 2010. What Accounts for Military Interventions in Politics: A Cross-National

Comparison. http://www.eakademi.org/incele.asp?konu=WHAT\%20ACCOUNTS\%20FOR\%20MILITARY\%20INTERVENTIONS\%20IN \%20POLITICS:\%20A\%20CROSSNATIONAL\%20COMPARISON\&kimlik=1285708304\&url=makaleler/monder-1.htm>. Consulted 19 October 2013

Pinkey, R. 1990. Right-Wing Military Government. London: Pinter

The New York Times 2014. Thai Army Declares Coup, Citing Need to Reform Nation. <http://www.nytimes.com/2014/05/23/world/asia/ thailand-military-coup.html?_r=0>. Consulted 23 May 2014

Wikipedia 2013. Regime. <http://en.wikipedia.org/wiki/Regime>. Consulted 16 October 2013 